\title{
THE ATA SYSTEM: ITS ORIGIN, DEVELOPMENT AND SOCIO-ECONOMIC IMPACT ON THE SOCIETY OF MEDINA DURING THE ERAS OF THE RIGHTLY GUIDED CALIPHS (11-40AH/632-661AD)
}

\author{
Elkhalifa Mohamed Omer*
}

\begin{abstract}
There were limited economic resources during the time of the Prophet, and this in turn affected the way of life adopted by the Medinans. Consequently, economic problems remained one of the main difficulties facing the new community in Medina. As a result of the Futuh, during the time of the Rightly Guided Caliphs, the financial and economic institutions of the state were developed along with the resources of the Treasury. This in its turn led to the establishment of a payment system by the state which came to be known by the name of Ata (stipend). The major aim of this study is to shed light on some of the social and economic impacts of the Ata on the society of Medina during the time of the Rightly Guided Caliphs. The study concludes that establishment of the Ata produced an improvement of the economic situation of some Medinans who invested this amount of money in other economic activities, and this improvement in its turn affected the way they lived. Others failed to make profitable use of this regular income, while some abandoned their traditional sources of income, and became dependent on their stipends. TheAta had a negative effect on the involvement of the Medinans in trade, which started to decline as Quraysh's principal or traditional source of income.
\end{abstract}

Keywords: Impacts, Ata, Society, Medina, Caliphs

\section{Introduction}

There were limited economic resources during the time of the Prophet and the first caliph, and this in turn affected the way of life adopted by the Medinans. Consequently, economic problems remained one of the main difficulties facing the new community in Medina. Although the Prophet tried to encourage agriculture and organized the markets, and although the Muslims won their wars with the Meccans and concluded some peace treaties with Ahl al-Dhimmah, the revenue from all these did not require the establishment of a finance office. The Prophet simply sent his representatives to collect the taxes (ushur, sadaqah, ${ }^{1}$ and zakah) from the tribes.

There was still no radical change during the time of the first caliph and, although the Riddah wars and the start of the Conquests brought new income to the state, this new source of income, even alongside the other income, did not reach an amount inducing the state to introduce a system of permanent stipends or Ata. The largest stipends received by the Medinans during the time of Abu Bakr amounted to only twenty dirhams. ${ }^{2}$ It is clear from the sources that there were indeed some rich persons, but the average Medinan's life remained simple.

During the period of Umar and as a result of the Conquests, income increased and new sources of funding were found. These sources were the jizyah, kharaj, and spoils of war (khums). All the money gathered from these sources used to be sent to the caliph in Medina to be distributed according to his orders. We read in the reports that an annual tribute was imposed on the people of al-Hirah in return for peace. Similar terms were also made for the people of Anbar. ${ }^{3}$ Evidence of this is found in the speech attributed to Umar when he received some booty from Yemen. On that occasion he addressed the Muslims in Medina saying, "We have received a huge amount of money. If you want us to count it out

\footnotetext{
* Elkhalifa Mohamed Omer (PhD), Department of History, Khartoum University, P O Box 321, 11115 Khartoum, Sudan. Email:kmomer@uofk.edu.

${ }^{1}$ Anything given in charity; see Muhammad b. Mukarram Ibn Manzur (n.d.), lisan al-Arab, Vol. 10, Beirut: Dar Sadir, pp. 196-197; Weir, T. H. \& Zysow A. (1995), "Sadaka," in C. E. Bosworth et al. (eds), The Encyclopaedia of Islam, $2^{\text {nd }}$ edition, Vol. 8, Leiden: EJ Brill, pp. 708716.

${ }^{2}$ Abu Yusuf Yaqub b. Ibrahim (1397/1976-77), al-Kharaj, Q. M. al-Khatib (ed.), Cairo: al-Maktaba al-Salafiya, p. 45; Abu Abd Allah Muhammad b. Saad b. Mania (1975), al-Tabaqat al-kubra, Beirut: Dar Sadir, Vol. 3, p. 193; Aharon Ben Shemesh (1965), Taxation in Islam, Vol. 3, Leiden: EJ Brill, p. 68.

${ }^{3}$ Abu al-Abbas Ahmad b. Yahya b. Jabir al-Baladhuri (1412/1992), Futuh al-buldan, S. Zakkar (ed.), Beirut: Dar al-Fikr, pp. $283-289$.
} 
among you, we will do so, or if you prefer us to distribute it by weight, we will do so." ${ }^{4}$ It is also mentioned that the amount of tax collected (jibayah) from the Iraqi Lowlands (Sawad) during the time of Umar was 100,000,000 dirhams, ${ }^{3}$ which again reflects the huge increase in the revenue of the state during this period.

\section{Ata (Stipend)}

It is natural that after the increase in the revenue and its sources, the Muslims started to think about establishing a new body to organize the distribution of this new income. This thinking led to the establishment of the Stipend Register (Diwan al-Ata) by Umar, who was the first to create such a body in which the Muslims were registered according to their tribes and a certain amount of money (Ata) was allocated to everyone. Tribesmen were organized into pay units called arafa under the control of the arif who was responsible of the distribution of the Ata among its members and their mawali and had to keep the register (diwan) of the payee and their families. ${ }^{6}$ The register covered the people of Medina, the forces that participated in the conquests and those who migrated to join the garrisons in the provinces where similar diwans were set up in provincial capitals like Basra, Kufa and Fustat. ${ }^{7}$ The Diwan, established by Umar, ${ }^{8}$ was not a financial or administrative body, but served as a registry for the system set up to distribute the stipends. It was not intended as a treasury for saving money. Our concern here is to note the socio-economic impacts of the establishment of the Ata on the Medinans and not to speak in detail about the system of Ata in the Islamic state.

Some sources mention that the system of Ata was established after the Conquest of Iraq, when the caliph said, "I do not pay those who fought against the Prophet the same amount as those who fought with the Prophet". ${ }^{9}$ According to Abu Yusuf, Abu Bakr divided the income of the state among all the people, minors and adults, freemen and slaves, males and females, in equal shares so that everyone received seven and one third dirhams. In the following year, when more income arrived, the share of each person amounted to twenty dirhams. ${ }^{10}$ Some Muslims objected to this equal division which took no account of some people who, they thought, should have had preference on account of their virtues, early conversion to Islam, or rank. To these objectors Abu Bakr replied that virtues were rewarded by God, but in matters of subsistence equality was better than preference. However, Umar did not agree with this view, saying, "I cannot treat one who always fought against the Prophet in the same way as one who always fought with him." "11 Al-Yaqubi connects the establishment of the system of Ata with the arrival of certain revenue in Medina. When Abu Musa al-Ashari brought from the spoils of war 1,000,000 dirhams, Umar was so overwhelmed that he asked him to repeat the figure, which he did by saying, "I am bringing with me ten times one hundred thousand." Thereupon, Umar said, "If this is true, even the shepherd in Yemen will receive his share without blushing by asking for it." ${ }^{2}$ It is clear therefore that the organization of the Ata was not an administrative innovation introduced after the accession of Umar and that it was in fact the increase in the revenue which led to the creation of the Diwan al-Ata. Some reports mention the different methods adopted by Umar for dealing with monies before the introduction of the Ata system, while other reports speak mostly about the organization of the Ata after the occupation of vast areas and the increase of the revenue without giving any exact date for the establishment of the Diwaan. 13 Ibn Saad mentions the year $20,{ }^{14}$ but others suggest an earlier date. ${ }^{15}$

Ibn Sallam reports that when some bedouin asked Umar to distribute money to them, he replied, "Not before I finish with the sedentary people." to those who participated in the occupation. He thought of giving stipends to all the Muslims in Arabia,

\footnotetext{
${ }^{4}$ Abu Yusuf (1976-77), Khara,j, pp. 48-49.

${ }^{5}$ al-Baladhuri (1992), Futuh al-buldan, p. 314.

${ }^{8}$ Abu Jafar Muhammad b. Jarir al-Tabari (1967/76), Tarikh al-rusul wa al-muluk, M.A. Ibrahim (ed.), Vol. 3, Cairo: Dar al-Maarif, vol. 3, pp.613-19.

${ }^{9}$ Abu Yusuf (1976-77), Kharaj, p. 42; Ben Shemesh (1965), Taxation, p. 68.

${ }^{10}$ Abu Yusuf (1976-77), Kharaj, p. 45; Ben Shemesh (1965), Taxation, p. 68.

${ }^{11}$ Abu Yusuf (1976-77), Kharaj, p. 46; Ibn Saad (1975), Tabaqat, p. 296; Ben Shemesh (1965), Taxation, p. 68

${ }^{12}$ Ahmad b. Abi Yaqub b. Wadih al-Yaqubi (1883), Tarikh al-Yaqubi, ed. M.TH. Houtsma, Vol. 2, Leiden: EJ Brill, p. 170.

${ }^{13}$ Abu Ubayd, al-Qasim b. Sallam (1968), al-Amwal, M. Kh. Haras (ed.), Cairo: Matbaat al-Shuruq, pp. 235-39; Abu Yusuf (1976-77), Kharaj,

p. 45; Ben Shemesh (1965), Taxation, pp. 71-72.

${ }^{14}$ Ibn Saad (1975), Tabaqat, pp. 299-302.

15 al-Yaqubi (1883), Tarikh al-Yaqubi, p. 170; al-Baladhuri (1992), Futuh al-buldan, p. 150; Salih Ahmed al-Ali (1390/1970), "al-Ata fi alHijaz: tatawr tanzimahu fi al-auhud al-islamia al-ula," in Majalat al-majma al-ilmi al-iraqi, Vol. 20 , p. 41.

${ }^{16}$ Ibn Sallam (1968), al-Amwal, p. 240.
} 
but he did not implement this idea and registration remained limited to Medina. ${ }^{17}$ Accordingly, the Ata payments were distributed even to those who did not live permanently in the city. As noted previously, Umar did not follow Abu Bakr's way of distribution. He gave the highest amounts to those who fought at Badr, although there are different reports about the exact amount. Ibn Sallam mentions 6,000 dirhams, ${ }^{18}$ while others give other amounts, e.g. Ibn Saad mentions $4,000^{19}$ and other reports mention that he gave these people $5,000 .{ }^{20}$ As for the Ansar, sources vary as to their stipends, some stating $6,000,{ }^{21}$ some $4,000,{ }^{22}$ some $3,000,{ }^{23}$ and a number of reports mentioning $5,000 .{ }^{24}$ The last figure seems the most likely, as it goes with the general principle of equality between the Muhajirun and Ansar. ${ }^{25}$ Umar also gave stipends of 4,000 dirhams to those who converted to Islam by the time of Badr, even though they did not participate in that battle. ${ }^{26} \mathrm{Ibn}$ Saad mentions that he gave stipends of 4,000 dirhams to those who migrated to Abyssinia and participated in Uhud. ${ }^{27}$ There are different reports concerning those who accepted Islam after the occupation of Mecca. Al-Tabari mentions that Umar gave stipends of 3,000 dirhams to those who accepted Islam after Hudaybiyah (6/628) up to the end of the Riddah wars (11/632). This would include those who had joined the armies of the Conquests in the time of Abu Bakr. Ibn Saad mentions that he gave them 2,000 dirhams. Other reports related by Ibn Saad claim that Umar gave them 800 dirhams. ${ }^{28}$ Al-Yaqubi mentions that he gave those who stayed in Mecca either 700 or 600 dirhams. 29

It is clear that al-Tabari's and Ibn Saad's reports are similar and in line with the previous ones, but the report of al-Yaqubi does not agree with the previous ones. It seems possible that Umar gave those who accepted Islam and participated in the occupation 2,000 dirhams, while to those who accepted Islam but did not participate in the Conquests he gave 800 dirhams. $^{30}$

According to some sources, Umar also gave the sons of the earlier Muslims 2,000 dirhams, as is confirmed by other reports. ${ }^{31}$ Ibn Saad also mentions that Umar gave the young Muhajirun and Ansar stipends equivalent to those awarded to the people who accepted Islam during the occupation of Mecca. ${ }^{32}$ Umar also allotted special amounts to his son Ibn Umar(3,000 dirhams), to Umar b. Abu Salamah (4,000 dirhams), and to Usamah b. Zayd (4,000 dirhams); some reports, e.g. Ibn Saad, ${ }^{33}$ mention 3,500 dirhams. Children qualified for stipends after they were weaned, but later the caliph changed the criterion, allowing them to qualify from the day of their birth. According to some reports, this took place after the caliph discovered that a Medinan woman tried to stop her baby breast-feeding before he was old enough in order to make him eligible for the Ata. ${ }^{34}$ This seems to suggest that some families depended principally on their Ata for their livelihood. Umar also awarded stipends to abandoned children and included them in the payment system. Ibn Saad mentions that he allocated to each abandoned child 100 dirhams as well as commodities, and he awarded expenses for their feeding and other things from the finance office. ${ }^{35} \mathrm{Al}$-Baladhuri mentions that the living expenses of abandoned children were met from the finance office. ${ }^{36}$ Some reports indicate that Uthman gave a new-born baby 50 dirhams at birth and then raised the amount to 100 dirhams when the child became one year old. Ibn Sallam mentions that he also awarded clothing to the child. ${ }^{37}$

\footnotetext{
${ }^{17}$ Ibn Saad (1975), Tabaqat, pp. 299-302; al-Ali (1970), “al-Ata fi al-Hijaz,” p. 43.

${ }^{18}$ Ibn Sallam (1968), al-Amwal, p. 238.

${ }^{19}$ Ibn Saad (1975), Tabaqat, p. 301.

${ }^{20}$ Ibn Sallam (1968), al-Amwal, pp. 237-38; AbuYusuf (1976-77), Kharaj, pp. 46-49.

${ }^{21}$ Ibn Sallam (1968), al-Amwal, p. 238; Ibn Saad (1975), Tabaqat, pp. 396-305.

${ }^{22}$ Ibn Sallam (1968), al-Amwal, p. 237; al-Yaqubi (1883), Tarikh al-Yaqubi, p. 175.

${ }^{23}$ Abu Yusuf (1976-77), Kharaj, p. 49; Ben Shemesh (1965), Taxation, p. 71.

${ }^{24}$ Abu Yusuf (1976-77), Kharaj, p. 46; Ibn Sallam (1968), al-Amwal, p. 237; Ben Shemesh (1965), Taxation, p. 69.

${ }^{25}$ al-Ali (1970), "al-Ata fi al-Hijaz," 43.

${ }^{26}$ Abu Yusuf (1976-77), Kharaj, 46; Ben Shemesh (1965), Taxation, p. 69.

${ }^{27}$ Ibn Saad (1975), Tabaqat, p. 297.

${ }^{28}$ Ibn Saad (1975), Tabaqat, pp. 297-99.

29 al-Yaqubi (1883), Tarikh al-Yaqubi, p. 175.

30 al-Ali (1970), "al-Ata fi al-Hijaz," p. 45.

${ }^{31}$ E.g. Abu Yusuf (1976-77), Kharaj, p. 46.

${ }^{32}$ Ibn Saad (1975), Tabaqat, pp. 297-300.

${ }^{33}$ Ibn Saad (1975), Tabaqat, p. 297.

34 al-Baladhuri (1992), Futuh al-buldan, p. 502.

${ }^{35}$ Ibn Saad (1975), Tabaqat, p. 304

${ }^{36}$ al-Baladhuri (1992), Futuh al-buldan, p. 495.

${ }^{37}$ Ibn Sallam (1968), al-Amwal, p. 250.
} 
Reports differ about the Ata allocated to the Prophet's wives. They are almost all agreed that Umar gave 'Aishah 12,000 dirhams, but they differ as to what he gave the others. ${ }^{38}$ Some mention 12,000 dirhams. Al-Yaqubi states that he gave Umm Habibah and Hafsah 12,000 dirhams and the rest 10,000 dirhams. ${ }^{39}$ Other reports state that he gave Safiyah and Juwayriyah $6,000 .{ }^{40}$ It is most probable that Umar actually gave 'Aishah 12,000 and the rest 10,000, because there was no justification for giving any one of the others more than the rest, while preferential treatment for 'Aishah could be justified on the grounds of her position and that of her father. ${ }^{41}$

Umar also gave women among the early Muhajirun, e.g. Asma bint 'Umays and Asmabint Abi Bakr, 1,000 dirhams. In different reports he is also said to have given Safiyah bint 'Abd al-Muttalib 6,000 dirhams, while he gave to women among the early Muhajirun 3,000 dirhams. ${ }^{42} \mathrm{Al}$-Tabari mentions that he gave those women who attended Badr 500 dirhams, those who converted to Islam between Badr and Hudaybiyah 400 dirhams, and those who came after that until the Conquests 300 dirhams. ${ }^{43}$ It seems probable enough that the Muhajirat were indeed preferred by being allotted 1,000 dirhams while the rest received the amount reported by al-Tabari. ${ }^{44}$

It seems that Umar thought of changing the system of distribution but died before doing so. According to reports Umar said, "If I survive until the next year, I will give all Muslims the same amount." ${ }^{45}$ It is clear that the early converts in general and the Medinans in particular were favoured by Umar 's basis of distribution.

We read that Uthman increased the amount of the Ata. Al-Tabari mentions that he was the first caliph to increase the Ata by 100 dirhams and that he gave each of the recipients of stipend (ahl al-fay) one dirham per day during Ramadan (the ninth month of the Muslim calendar). He also gave the Prophet's wives two dirhams. When he was asked to make a feast for the Medinans, he said, "I had to make them satisfied in their homes" and he continued the policy of the second caliph by providing a feast in Ramadan, saying that it was for the worshippers and the 'followers of the way'. ${ }^{46}$ Al-Yaqubi mentions that Uthman gave to the Muslims equally but preferred his relatives, ${ }^{47}$ but he does not mention the precise amount or say whether he gave them the highest Ata or introduced something in between, by raising the lower and reducing the higher. ${ }^{48}$ Neither does the report explain to us whether this equality was a temporary one or whether Uthman reverted to Umar 's system. There is nothing in the sources about this. The other possibility is that Uthman raised the Ata of his relatives to make it equal to the Ata of the early Muhajirun. ${ }^{49}$

Ali allotted equal Ata to the mawali, youths , the Muhajirun, and the Ansar. ${ }^{50}$ It seems that the attempt of Ali to distribute the stipend equally between all Muslims led some of those who benefited from Umar's bases of distribution to join the opposition against him. ${ }^{51}$

As already mentioned, many people of non-Arab origin joined Islam in its early days, and some of them received Ata. We read that Umar gave the mawali who participated in Badr the same amount that he gave to the Muhajirun and Ansar. ${ }^{52}$ Ibn Saad mentions that he allotted stipends to them according to their status, determined according to the time of their conversion to Islam, their participation in the jihad, and other factors. The rest he included in one category and added to them those who migrated to Medina. He also gave stipends to freed slaves. ${ }^{53}$ Some sources mention that he gave al-Hurmuzan, the

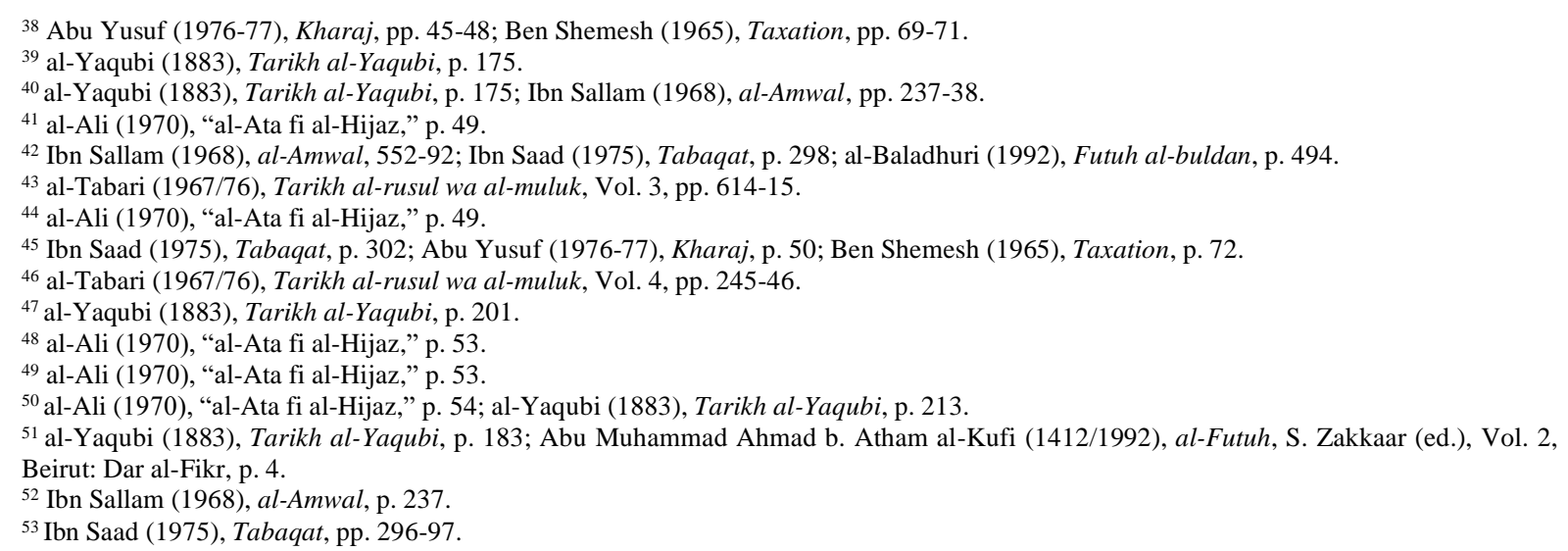


former Persian commander of Tustar, 2,000 dirhams, ${ }^{54}$ but this was owing to special circumstances, not a general rule. ${ }^{55}$ This is evidenced in a number of reports indicating the exclusion of the slaves from the Ata. ${ }^{56}$

Abu Bakr's policy of equality was perhaps applied during the time when the Muslims were few in number, when Islam was still centred in Arabia, when most of the Muslims were Arabs, and when the centre of these activities was Medina, where Umar organized the Ata. Following the Conquests, many of the mawali and slaves migrated to Medina, attracted there by the flourishing economic life and no doubt some of them were included in the Ata while the others were left outside the system. ${ }^{57}$ Sources mention a number of reports indicating the exclusion of the slaves from the Ata. ${ }^{58}$

It is clear that Abu Bakr distributed equally to stipend-holders without any preference, but Umar excluded slaves and introduced grading according to the time of conversion and relationship to the Prophet. Ali tried to reintroduce the policy of Abu Bakr. ${ }^{59}$ It is natural that such a policy would be met by strong opposition from those who saw the Ata as a token of social status and those who benefited from some of Uthman's policies. This is evident in a report attributed to Ibn Abbas, a leading Medinan and supporter of the fourth caliph. According to this report, Ibn Abbas mentioned that one of the reasons behind the opposition to Ali was his attempt to change the Ata system. ${ }^{60}$

The Ata was awarded to fighters on condition that they would fight when needed. It is clear that the Medinans formed one of the main powers in the Muslim army in the time of the Prophet and the Riddah wars and that some of them participated in the Conquest armies. The expansion of the state and the increase in the numbers of Arabs from outside the city who joined the armies led the caliph to establish the garrison cities (amsar, orajnad) and make these garrison cities permanent bases for the Muslim army. As a result, the duty of fighting fell mainly on these garrisons and not only on the Medinans, who only obeyed the call when needed.61

\section{Arzaq (Provisions)}

The Ata was not only a monetary payment, as there were other types of Ata, e.g. in clothes or perfume. The Medinans also received some commodities as part of their Ata and these were known as arzaq (sing. rizq). Ibn Shabbah mentions that during the time of Uthman no day passed without the distribution of provisions, e.g. clothes, honey, and ghee (samn). ${ }^{62}$ This report goes on to mention that the Ata was plenty and the enemy was subjected. According to several sources, two jaribs ${ }^{63}$ of flour were received each month by men, women, and slaves starting from the time of Umar. ${ }^{64}$ This report explains that Umar distributed the provisions equally on the basis of the average person's consumption, which was not a fixed amount. By the time of Uthman, with the improvement in the economic situation, Uthman increased the amounts of provisions and clothes. It seems that amounts were not permanently fixed, but varied according to changes in the size of the units' length and weight. ${ }^{65}$ Al-Tabari, records that alAhnaf $b$. Qays (a delegation from Basra) asked Umar to increase the size of the measuring units. ${ }^{66}$ Although we find no explanation of the connection between the change in size and the rizq, it is clear that the change did affect the amount. ${ }^{67}$ Al-Waqidi mentions that Umar favoured the Muslims in the

\footnotetext{
${ }^{54}$ Ibn Saad (1975), Tabaqat, p. 60.

${ }^{55}$ Abd al-Aziz Abd al-Karim al-Duri, et al., (1991) "Diwan," in B. Lewis et al (eds), The Encyclopedia of Islam, New Edition, Leiden: EJ Brill, Vol. 2, 323; al-Ali (1970), “al-Ata fi al-Hijaz," pp. 71-72.

${ }^{56}$ Ibn Saad (1975), Tabaqat, pp. 300-02.

${ }^{57}$ al-Ali (1969), al-Tanzimat al-ijtimaiyyaa wa al-iqtisadiyya fi al-basrah fi al-qarn al-awal al-hijri, Beirut: Dar al-Taliaa, p. 99; al-Ali (1970),

"al-Ata fi al-Hijaz," p. 72.

${ }^{58}$ Ibn Saad (1975), Tabaqat, pp. 295-302; Ibn Sallam (1968), al-Amwal, pp. 253-257.

59 al-Kufi (1992), al-Futuh, p. 4; al-Yaqubi (1883), Tarikh al-Yaqubi, pp. 151-154.

60 al-Kufi (1412/1992), al-Futuh, p. 4; Muhammad Umarah (1971), al-Khilafah al-Islamiyyahwa-nashat al-ahzab al-siyasiyyah, Beirut: Dar al-Taliaa, p. 144.

61 al-Ali (1970), “al-Ata fi al-Hijaz," p. 74.

62 Abu Zayd Umar b. Shabbah (1403/1983), Tarikh al-Madinah al-munawwarah, F. Shaltut (ed.), Vol. 3, Jeddah: Dar al-Asfahani, p. 1023.

${ }^{63}$ A grain measure of capacity of around $256 \mathrm{lbs}$., also a measure of land 60 cubits square. On its various uses, see Ibn Sallam (1968), alAmwal, pp. 260-61, 512-33; Walter Hinz (1955), Islamische Masse und Gewichte, Leiden: EJ Brill, pp. 65-66.

${ }^{64}$ Ibn Saad (1975), Tabaqat, p. 305; al-Tabari (1967/76), Tarikh al-rusul wa al-muluk, Vol. 3, p. 615; al-Ali (1969), al-Tanzimat, pp. $173-74$.

${ }^{65}$ For more details, see al-Tabari (1967/76), Tarikh al-rusul wa al-muluk, Vol. 4, pp. 75, 278.

66 al-Tabari (1967/76), Tarikh al-rusul wa al-muluk, Vol. 4, p. 75.

${ }^{67}$ al-Ali (1970), “al-Ata fi al-Hijaz,” pp. 81-82.
} 
food imported via al-Jar. But we do not know anything about the impact of changes on the quantities of provisions which were made from the time of Umar to the time of Ali. ${ }^{68}$

The conquered areas provided the Medinans with a means of supplementing their own products. During this period, we find that al-Jar became the main base for the distribution of Egyptian imports. The search for securing a permanent supply for the Medinans led to the ordering of the excavation of an old canal linking Egypt to the Red Sea. Al-Tabari informs us that 'Amr b. al-Aas, the governor of Egypt, told Umar that if he wanted the price of food in Medina to be on the same level as that in Egypt, he (Amr) would excavate an old canal which had been dug to the Mediterranean and also had an outlet into the Red Sea but which the Byzantines and Copts had made unusable. He pointed out, however, that this might have a negative impact on the economy of Egypt and the amount of kharja raised. Umar ordered him to carry out this project and, as a result, the food prices in Medina reached the level of those in Egypt. ${ }^{69}$ Umar built stores (qusur) and food was distributed according to documents (sukuk, sing. sakk) issued by the caliph and sealed under his seal. ${ }^{70}$ It seems that some of the Medinans would have sold their documents because most of the Medinans were farmers who were able to meet their needs from their own produce, so that they were not in need of them. As a result, the trade in these receipts became common in Medina and led to a lot of debate between religious men and in religious circles. ${ }^{71}$ It is clear that some people used to sell their document (sakk) as soon as they received it, indeed before it was due, and they would give the buyer the document to cash. When one of the Medinans sold his before its due date, Umar ordered him not to do so. ${ }^{72}$ During the time of Umar people used to receive their Ata at the beginning of the month Muharam (the first month of the Islamic Calendar).

Sometimes the caliphs used to distribute garments among the Medinans. It is reported that the caliph receivedgarments and items of clothing (hulal) from Yemen and distributed them among the Companions, reserving one for Abu Ayyub al-Ansari, who was not in the city at that time. ${ }^{74}$ It is probable that most of the Medinans' clothing came from Yemen, Egypt, Syria, Iraq, Qatar, and Persia and through the treaties they signed with defeated peoples. Some clauses of the treaties drawn up with the defeated peoples stipulated the supplying of the city with clothing. Sources state that Umar ordered the registration of the children of al-Awali and that he used to distribute commodities to them. They add that Uthman increased the commodities and clothing, so that Ata and clothing were increased during that period. ${ }^{75}$

To appreciate the impact of the introduction of the Ata on social life, we have to make some general comments on the level of prices during this period. The state followed a free trade policy and allowed free movement for traders and their trades between the different parts of the state. No doubt this policy led to the monopoly of some goods by some traders, although it is clear from our sources (which reflect the views of the time) that monopoly was regarded by the people as a disgrace and, besides, these monopolies were, in any case, limited and for a short period and there are no reports that they had any effect on prices.

It seems that the state did not interfere in prices or impose them and there are a number of sayings attributed to the Prophet which confirm this and also his refusal to interfere in this matter during crisis times. ${ }^{76}$ Also, the payment of taxes imposed on farmers in kind or money would have an indirect impact on the stabilization of prices, as farmers were not under pressure to sell some of their produce to pay taxes. Further, the distribution by the state of barley helped to keep its price stable.

\footnotetext{
${ }^{68}$ al-Yaqubi (1883), Tarikh al-Yaqubi, p. 301; al-Ali (1970), “al-Ata fi al-Hijaz,” p. 82.

69 al-Tabari (1967/76), Tarikh al-rusul wa al-muluk, Vol. 4, p. 100; Gautier H. A. Juynboll (1989), The History of al-Tabari, Vol. 13, New York: State University of New York Press, pp. 154-159.

${ }^{70}$ al-Yaqubi (1883), Tarikh al-Yaqubi, p. 177.

${ }^{71}$ Abd al-Rahman b. Abd Allah b. Abd al-Hakam (1922), Futuh Misr wa-akhbaruha, C.C. Torrey (ed.), New York: New Haven, p. 224;

Malik b. Anas (1370/1951), al-Muwatta, M. Fuad (ed.), Vol. 2, Cairo: Isa al-Babi al-Halabi, pp. 643-650.

${ }^{72}$ Malik b. Anas (1951), al-Muwatta, p. 63.

${ }^{74}$ Shams al-Din Muhammad b. Ahmad al-Dhahabi (1994) Nuzhat al-fudala: Tahdhib siyar alam al-nubala, Vol. 5, Jeddah: Dar al-Andalus, p. 40 .

75 al-Baladhuri (1992), Futuh al-buldan, p. 495; Ibn Saad (1975), Tabaqat, p. 297.

${ }^{76}$ Abu Daud Sulayman b. al-Ashath (1985), Sunan Abu Daud, M. Abd al-Hamid (ed.), Vol. 2, Cairo: Mustafa al-Babi al-Halabi, p. 244; Nur al-Din Ali b. Ahmad al-Samhudi (1374/1955), Wafa al-wafa bi-akhbardar al-Mustafa, M. Muhyi al-Din (ed.), Vol. 2, Cairo: Dar alSaada, pp. 556-57.
} 
The Ata System: Its Origin, Development and Socio-Economic Impact on the Society of Medina

The Conquests led to the availability of luxury commodities, so that the Muslims were able to obtain many valuable items and sell them cheaply to other provinces. The prices of animals can be deduced from the numbers of animals that had to be paid for blood money during the time of Umar : either 1,000 dinars, 12,000 dirhams, 100 camels, 200 cows, or 2,000 goats, which means that the price of a camel was 120 dirhams, a cow 60 dirhams, and a goat 6 dirhams. ${ }^{77}$ This was the average and no doubt the price of an animal of good quality was higher still.

The distribution of the Ata had an effect on social life in that this fixed and regular stipend might well restrict the consumer power of individuals, especially those who relied principally on it for their subsistence. In addition, the regular amount of corn distributed to individuals may well have helped to keep the price of this important commodity under control. ${ }^{78}$ Nevertheless, the system provided some sort of stability for those who relied on the Ata as their main source of income. On the other hand, the Ata led to an improvement in the economic situation of some Medinans who invested this amount of money in other economic activities, e.g. trade and agriculture, and this improvement in its turn affected the way they lived. Some others failed to make use of this regular money and some abandoned their traditional sources of income, e.g. trade and agriculture, and became dependent on this stipend and on the manual labour of their slaves. ${ }^{79}$ Evidence of this is found in Ibn Shabbah's report that when the Medinans asked Umar about the market, he said to them, "I saw that most of those dealing in the markets were mawali and there were only a few Arabs." The Medinans' reply to his criticism was that they had enough from spoils of wars (al-fay) and hated to do inferior work which their slaves could do for them. ${ }^{79}$

\section{Conclusion}

The study shows that the increase in the state revenue led to the establishment of the Stipend Register (Diwan al-Ata) by Umar. The registration was carried out by tribes and Ata, fixed salaries or stipends were granted according to the date each recipient converted to Islam or joined the Conquests movement. In addition to the regular pay the Medinans also received some commodities as part of their Ata and these were known as arzaq. The Ata in turn led to the improvement of the economic situation of some Medinans who invested this amount of money in other economic activities, e.g. trade and agriculture, and this improvement in its turn affected the way they lived. Others failed to make profitable use of this regular income, while some abandoned their traditional sources of income, e.g. trade and agriculture, and became dependent on their stipends and on the manual labour of their slaves and mawali or on hiring others to do their work for them. The Ata had a negative effect on the involvement of the Medinans in trade, which started to decline as Quraysh's principal or traditional source of income.

\section{References}

Abu Daud, Sulayman b. al-Ashath b. Ishaq (1985), Sunan Abu Daud, M. Abd al-Hamid (ed.), 4 Vols., Cairo: Mustafa al-Babi al-Halabi

Abu Yusuf, Yaqub b. Ibrahim (1397/1976-77), Kitab al-Kharaj, Q. M. al-Khatib (ed.), Cairo: alMaktabah al-Salafiyah.

al- Harbi, A. Kh. (1988), "Tawzi al-Ata ala al-Jund fi fatratay sadr al-Islam wa al-Ahd al-Abasi alAwal," Majallat al-Mawrid, Vol. 17, no.3, 21-31.

al-Ali, Salih Ahmed (1390/1970), "al-Ata fi al-Hijaz: tatawwur tanzimahu fi al-auhud al-islamiah alula," in Majallat al-majma al-ilmi al-iraqi, Vol. 20, 37-87.

al-Ali, Salih Ahmed (1969), al-Tanzimat al-ijtimaiyyaa wa al-iqtisadiyya fi al-basrah fi al-qarn al-awal al-hijri, Beirut: Dar al-Taliaa.

\footnotetext{
${ }^{77}$ Malik b. Anas (1370/1951), al-Muwatta, pp. 848-83; al-Ali (1969), al-Tanzimat, pp. 173-74; Ibn Shabbah (1983), Tarikh al-Madinah, Vol. 2, pp. 757-58.

78 al-Ali (1969), al-Tanzimat, p. 173-74

${ }^{79}$ See Elkalifa Mohamed Omer (2009), "Impact of the early Islamic Conquests on the social structure of Medina," Journal of the International Institute of Islamic Thought and Civilization, Vol. 13, no. 2, pp. 213-221; Elkalifa Mohamed Omer (2005), Some of the social and economic impacts of the Early Islamic Conquests (Futuh) on Medina, PhD thesis, Manchester University, pp. 129-130, 156-172.

${ }^{79}$ Ibn Shabbah (1983), Tarikh al-Madinah, Vol. 3, p. 899.
} 
Journal of Al-Tamaddun, Vol. 15 (1), 2020, 109-117

al-Bakri, Abd Allah b. Abd al-Aziz al-Andalusi (1364-71/1945-51), Mujamma istajam min asma almawadi, M. al-Saqqa (ed.), 4 Vols., Cairo: Matbaat Lajnat al-talīf wa al-tarjama wa al-Nashr.

al-Baladhuri, Abu al-Abbas Ahmad b. Yahya b. Jabir (1412/1992), Futuh al-buldan, S. Zakkar (ed.), Beirut: Dar al-Fikr.

al-Dhahabi, Shams al-Din Muhammad b. Ahmad (1994), Nuzhat al-fudala: Tahdhib siyar alam alnubala, 3 Vols., Jeddah: Dar al-Andalus

al-Samhudi, Nur al-Din Ali b. Ahmad (1374/1955), Wafa al-wafa bi-akhbar dar al-Mustafa, M. Muhyi al-Din, 4 Vols., Cairo: Dar al-Saadah.

al-Yaqubi, Ahmad b. Abi Yaqub b. Wadih (1883), Tarikh al-Yaqubi, M.TH. Houtsma (ed.), 2 Vols., Leiden: Brill.

Ben Shemesh, A. (1965), Taxation in Islam, 3 Vols., Leiden: EJ Brill

Duri, Abd al-Aziz Abd al-Karim, et al., (1991) "Diwan," in B. Lewis et al (eds.), The Encyclopedia of Islam, $2^{\text {nd }}$ edition, Vol. 2, Leiden: EJ Brill, 323-337.

Gautier H. A. Juynboll (1989), The History of al-Tabari, Vol. 13, New York: State University of New York Press.

Hinz, W. (1955), Islamische Masse und Gewichte, Leiden: EJ Brill.

Ibn Abd al-Hakam, Abd al-Rahman b. Abd Allah (1922), Futuh Misr wa-akhbaruha, C.C. Torrey (ed.), New York: New Haven.

Ibn Atham, Abu Muhammad Ahmad b. Atham, al-Kufi (1412/1992), Kitab al-Futuh, S. Zakkaar (ed.), 3 Vols., Beirut: Dar al-Fikr

Ibn Manzur, Muhammad b. Mukarram (n.d.), Lisan al-Arab, 15 Vols., Beirut: Dar Sadir.

Ibn Sad, Muhammad b. Saad b. Mania (1975), al-Tabaqat al-kubra, 9 Vols., Beirut: Dar Sadir.

Ibn Sallam, Abu Ubayd al-Qasim b. Sallam (1968), Kitab al-Amwal, M.Kh. Haras (ed.), Cairo: Matbaat al-Shuruq.

Ibn Shabbah, Abu Zayd Umar b. Shabbah (1403/1983), Tarikh al-Madinah al-munawwarah, F. Shaltut (ed.), Jeddah: Dar al-Asfahani.

Malik b. Anas (1370/1951), al-Muwatta, M. Fuad (ed.), Cairo: Isa al-Babi al-Halabi.

Omer, Elkhalifa Mohamed (1987), al-Hayah al-ijtimaiyyah fi al-Madinah fi ahd al-khulafa al-rashidin, master thesis, Khartoum University.

Omer, Elkhalifa Mohamed (2005), Some of the social and economic impacts of the Early Islamic Conquests (Futuh) on Medina, $\mathrm{PhD}$ thesis, Manchester University.

Omer, Elkhalifa Mohamed (2009), "Impact of the early Islamic Conquests on the social structure of Medina," Journal of the International Institute of Islamic Thought and Civilization, Vol. 13, no.2, 209228.

P.K. Hitti \& F.C. Murgotten (1916-1924), The Origin of the Islamic state, 2 Vols., New York: Columbia University.

Tabari, Abu Jafar Muhammad b. Jarir (1967/76), Tarikh al-rusul wa al-muluk, M.A. Ibrahim (ed.), 10 Vols., Cairo: Dar al-Maarif. 
The Ata System: Its Origin, Development and Socio-Economic Impact on the Society of Medina Umarah, Muhammad (1971), al-Khilafah al-Islamiyyah wa-nashat al-ahzab al-siyasiyyah, Beirut: Dar al-Talia.

Weir, T. H. \& Zysow A. (1995) "Sadaka," in Bosworth C. E. et al. (eds.), The Encyclopaedia of Islam, $2^{\text {nd }}$ edition, Vol. 8, Leiden: EJ Brill, 708-716. 
Journal of Al-Tamaddun, Vol. 15 (1), 2020, 109-117 